\title{
Copper fertiliser increases pasture copper concentration and improves the copper status of grazing sheep
}

\author{
S.O. KNOWLES ${ }^{1}$, N.D. GRACE ${ }^{1}$, J.R. ROUNCE ${ }^{1}$, D.M. WEST ${ }^{2}$ and J. LEE ${ }^{1}$ \\ ${ }^{1}$ AgResearch, Grasslands Research Centre, PB 11008, Palmerston North \\ ${ }^{2}$ Institute of Veterinary, Animal and Biomedical Sciences, Massey Univ, PB 11222, Palmerston North
}

\begin{abstract}
Application of copper-amended fertiliser ("topdressing") increases pasture herbage $\mathrm{Cu}$ concentration and can increase dietary $\mathrm{Cu}$ intake of grazing ruminants. Animal responses to dietary $\mathrm{Cu}$, in terms of changing blood and liver $\mathrm{Cu}$ concentrations monitored throughout the season, have not been well documented. In this study 10 experimental paddocks were topdressed with 0 (Control), 0.4 (Low) or 4.0 (High) $\mathrm{kg} \mathrm{Cu} / \mathrm{ha}$ as $\mathrm{CuSO}_{4} .5 \mathrm{H}_{2} \mathrm{O}$, resulting in mean herbage $\mathrm{Cu}$ concentrations of 8 , 13 and $41 \mathrm{mg} \mathrm{Cu} / \mathrm{kg} \mathrm{DM}$, respectively. The treated pastures were significantly greater than controls for at least 100 days. Romney lambs of low but not deficient initial $\mathrm{Cu}$ status grazing the $\mathrm{Cu}$-treated paddocks for 176 days had increased $\mathrm{Cu}$ intake compared with controls, resulting in substantial accumulation of $\mathrm{Cu}$ in liver. Maximum liver $\mathrm{Cu}$ concentration occurred after 99 days, when the levels in low- and high-treated sheep were 3 to 12 times greater than controls ( 900 to 3270 vs $270 \mathrm{mg}$ $\mathrm{Cu} / \mathrm{kg}$ fresh tissue). No changes in blood plasma $\mathrm{Cu}$ concentration were observed. A predictive relationship between pasture $\mathrm{Cu}$ and liver $\mathrm{Cu}$ concentrations of grazing lambs was determined, and recommendations for sheep $\mathrm{Cu}$ supplementation via $\mathrm{Cu}$ topdressing are made.
\end{abstract}

Keywords: copper status, copper supplementation, liver biopsy, Romney lambs, topdressing

\section{Introduction}

Cattle, sheep and deer in New Zealand grazing pastures low in copper $(\mathrm{Cu})$ and high in molybdenum (Mo) risk $\mathrm{Cu}$ deficiency. This can be prevented by suitable $\mathrm{Cu}$ supplementation strategies, including treatment with orally administered $\mathrm{CuO}$ needles, $\mathrm{Cu}$ injections, and the application of $\mathrm{Cu}$ to pastures with $\mathrm{Cu}$ (Grace 1994). Topdressing application of 2.5 to $20 \mathrm{~kg} \mathrm{CuSO}_{4} .5 \mathrm{H}_{2} \mathrm{O} /$ ha has been shown to increase pasture $\mathrm{Cu}$ content from 4 to $20 \mathrm{mg} \mathrm{Cu} / \mathrm{kg} \mathrm{DM}$, and can maintain these $\mathrm{Cu}$ concentrations for 9 to 12 months (Cunningham \& Perrin 1947). Factors such as season, soil type, pasture composition, and rate of $\mathrm{Cu}$ application will influence
$\mathrm{Cu}$ uptake by herbage, and ultimately affect plant $\mathrm{Cu}$ concentration and availability of $\mathrm{Cu}$ to the grazing animals (Adams \& Elphick 1956; Mitchell et al. 1957; Sherrell \& Rawnsley 1982). The effect of $\mathrm{Cu}$ application on pasture and its impact on dietary $\mathrm{Cu}$ intake of ruminants has yet to be fully characterised.

This study describes changes in the $\mathrm{Cu}$ status of Romney sheep grazing for 6 months on pastures of low to high $\mathrm{Cu}$ content, via monitoring concentrations of $\mathrm{Cu}$ in liver and plasma.

\section{Materials and methods}

As part of a larger study to determine the relationship between $\mathrm{Cu}$ intake and $\mathrm{Cu}$ status of grazing lambs (Grace et al. 1998), pastures were topdressed with various amounts of copper sulphate. Copper as $\mathrm{CuSO}_{4} .5 \mathrm{H}_{2} \mathrm{O}$ was thoroughly mixed with superphosphate fertiliser and the $\mathrm{Cu}$-amended fertiliser applied by hand in mid April at the rate of $250 \mathrm{~kg} / \mathrm{ha}$ to 10 experimental paddocks of mean area of $0.8 \mathrm{ha}$. The treatments were superphosphate with no additional $\mathrm{Cu}$ (Control); superphosphate plus $0.4 \mathrm{~kg} \mathrm{Cu} / \mathrm{ha}\left(1.6 \mathrm{~kg} \mathrm{CuSO}_{4} .5 \mathrm{H}_{2} \mathrm{O} /\right.$ ha; Low); superphosphate plus $4.0 \mathrm{~kg} \mathrm{Cu} / \mathrm{ha}(16 \mathrm{~kg}$ $\mathrm{CuSO}_{4} .5 \mathrm{H}_{2} \mathrm{O} / \mathrm{ha}$; High), on 3,3 and 4 paddocks, respectively.

Samples of herbage were gathered from all paddocks in early April to determine pre-experimental concentrations of $\mathrm{Cu}$ and other elements. About 2 weeks later, the fertiliser treatments were applied. This was designated as Day 1 of the study. Further herbage samples were collected on Days 30,65, 99, 141 and 374.

A flock of 100 8-month-old Romney lambs was used in this study. Fifty of these lambs were sourced from a Raupunga farm in the Wairoa district and had low but not deficient initial $\mathrm{Cu}$ status (13 mg (205 $\mu \mathrm{mol}) \mathrm{Cu} / \mathrm{kg}$ fresh liver tissue). The animals were transported to Ballantrae Research Station near Woodville and for 4 weeks before the experiment were grazed as a single flock. Liveweights were recorded on Days 1, 50, 141 and 175 of the study. On Day 17, the experimental lambs were eartagged, weighed, randomly assigned to experimental paddocks, and set stocked at 12 animals/ha. Two lambs from each paddock, about one fifth of the animals, were designated as monitor 
animals and liver biopsy samples were obtained from these on Day 1 and again on Days 51, 99 and 142. Blood was collected from 4 lambs per paddock on Days 17, 51, 99, 142 and 175. On Day 176, all lambs were slaughtered at a local abattoir.

\section{Collection and analysis of samples}

Herbage samples (400 g fresh pasture) were collected along the same 100-150 $\mathrm{m}$ transect in each paddock by cutting the sward down to 10 to $15 \mathrm{~mm}$ every 5 to $7 \mathrm{~m}$. Sub-samples were freeze-dried and ground before analysis for $\mathrm{Cu}$ and other elements. Blood was collected from the jugular vein into $7 \mathrm{ml}$ heparinised vacutainers specially prepared for trace element analysis. Following centrifugation, the plasma was removed and stored at $-20^{\circ} \mathrm{C}$. Liver samples of $50-100 \mathrm{mg}$ were obtained by the modified biopsy procedure of Dick (1944) under general anaesthesia. Samples were washed in $0.9 \%$ $\mathrm{NaCl}$, patted dry, and stored at $-20^{\circ} \mathrm{C}$.

Elemental composition of pasture, liver and plasma was determined by inductively coupled plasma (ICP) emission spectrometry (Lee 1983). In preparation for ICP analysis, freeze-dried samples $(0.5-1.0 \mathrm{~g})$ were digested in concentrated Analar $\mathrm{HNO}_{3}$ and the digest residue dissolved in $2 \mathrm{M} \mathrm{HCl}$. One-ml samples of plasma were digested in $0.5 \mathrm{ml}$ concentrated Analar $\mathrm{HNO}_{3}$ and $0.5 \mathrm{ml} 30 \% \mathrm{H}_{2} \mathrm{O}_{2}$ in polyethylene tubes in a waterbath for 2 hours at $90^{\circ} \mathrm{C}$.

Data were analysed by ANOVA and Duncan's multiple-range test, using procedures of Statistical Analysis System (SAS 1987). Liver Cu concentration data were subjected to $\log _{10}$ transformation before statistical analysis because of heterogeneity of variance among treatments.

\section{Results}

By Day $30 \mathrm{Cu}$ concentrations of herbage from treated pastures were significantly increased over preexperimental levels, and remained greater than those of controls for 99 and 141 days for the low-treated and high-treated pastures, respectively (Figure 1). By Day $374 \mathrm{Cu}$ concentrations had returned to baseline values. As no data are available to describe accurately pasture $\mathrm{Cu}$ responses during the latter half of the year, a simple gradual decline is estimated. From Days 30 through 141 the mean herbage $\mathrm{Cu}$ concentrations were 8,13 and $41 \mathrm{mg} \mathrm{Cu} / \mathrm{kg} \mathrm{DM}$ for control, low-treated and high-treated pastures, respectively.

Liver $\mathrm{Cu}$ concentration in animals grazing control pastures varied slightly with season but was not significantly changed from initial levels at the end of the 6-month trial (Figure 2). By Day 51 liver $\mathrm{Cu}$ concentrations in treated lambs were significantly increased over pre-experimental levels, and remained greater than those of control animals through slaughter on Day 176. Increasing mean pasture $\mathrm{Cu}$ concentrations resulted in substantial accumulation of $\mathrm{Cu}$ in liver. Maximum liver $\mathrm{Cu}$ concentration occurring on Day 99, when the levels in low-treated and high-treated sheep were three to 12 times greater than controls. There was no effect of pasture $\mathrm{Cu}$ treatment on blood plasma $\mathrm{Cu}$ concentrations; mean plasma $\mathrm{Cu}$ concentration for all

Figure 1 Effect of application rate of $\mathrm{Cu}$-amended fertiliser and season on the concentrations of $\mathrm{Cu}$ in mixed ryegrass/clover pasture over 12 months (mean \pm SEM, $n \approx 3$ ). O Control (0 Cu); œ Low $(0.4 \mathrm{~kg} \mathrm{Cu} / \mathrm{ha}) ; \square$ High (4.0 kg Cu/ha).

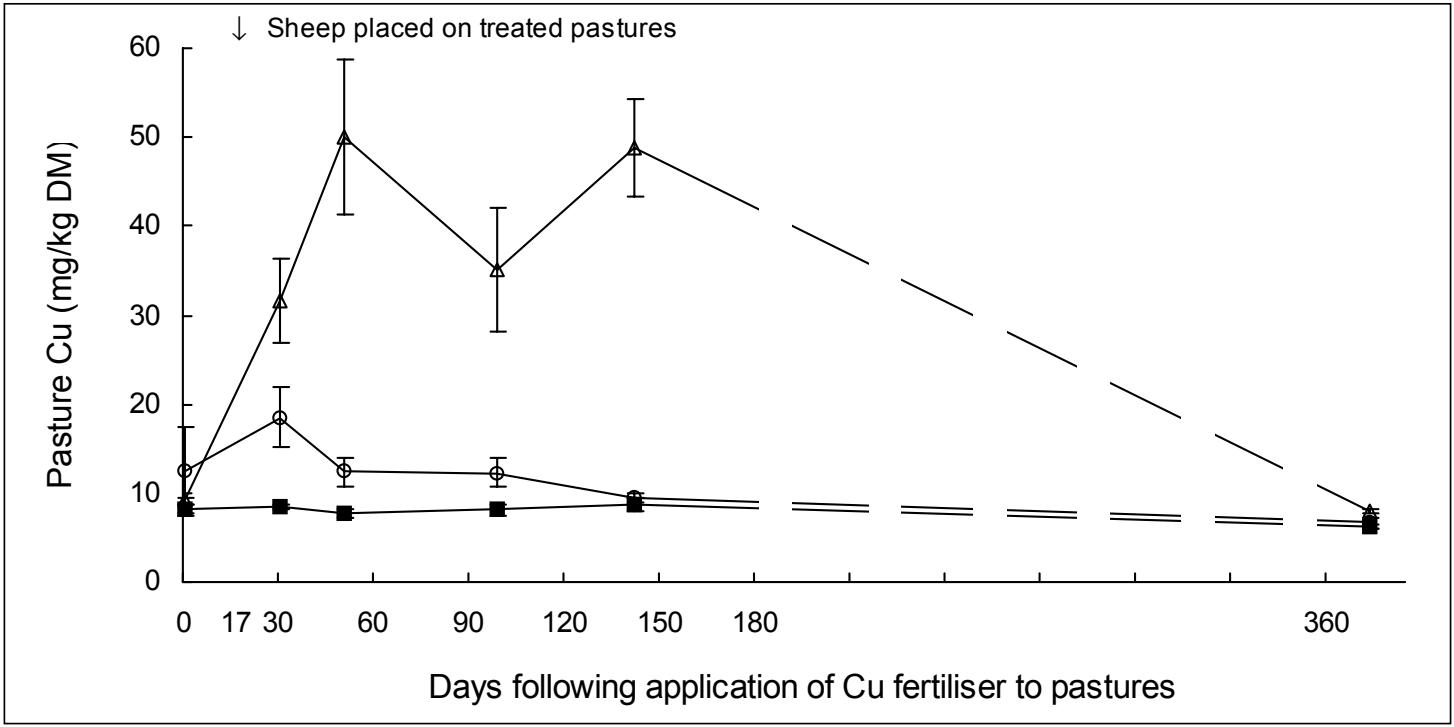


Figure 2 Effect of application rate of $\mathrm{Cu}$-amended fertiliser and season on liver Cu concentrations in grazing Romney sheep over 176 days

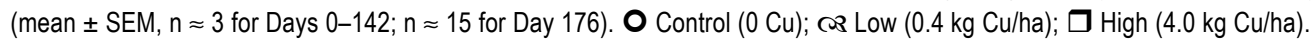

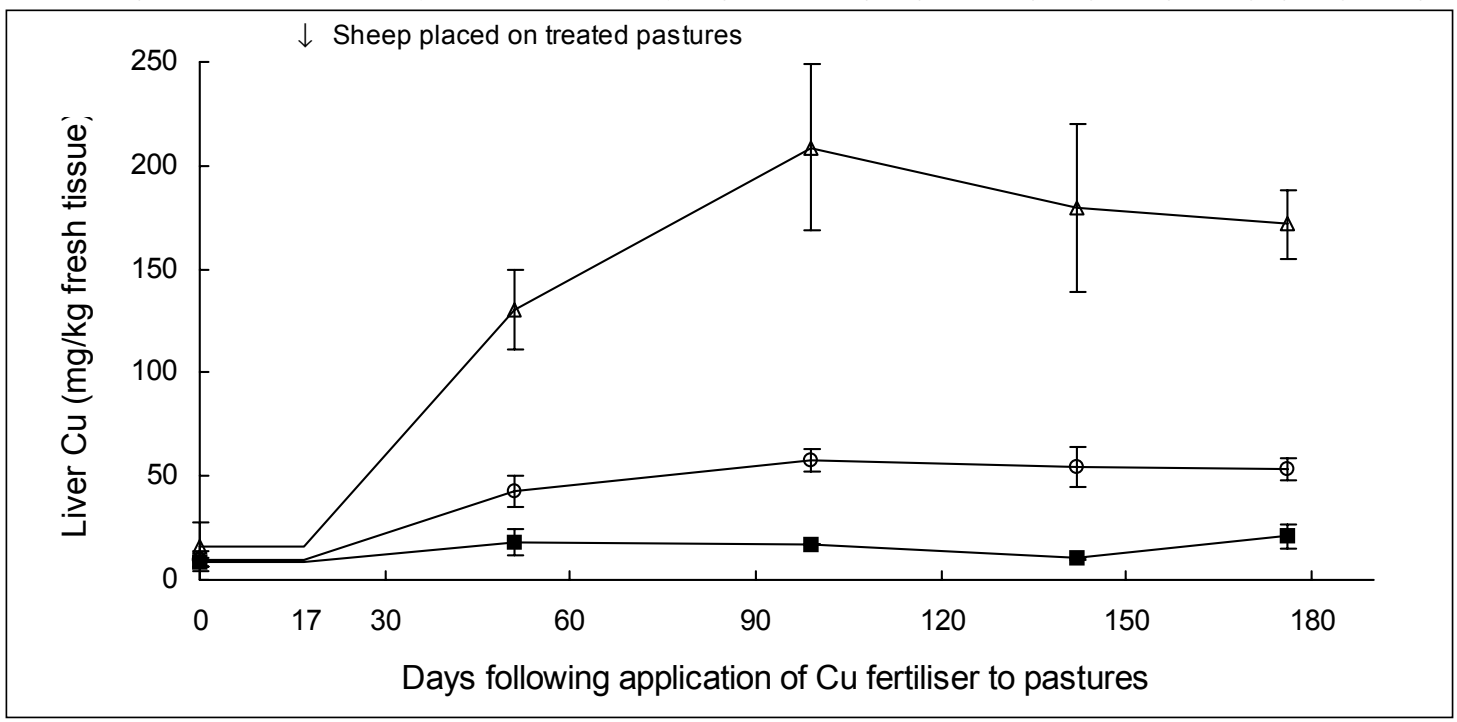

Figure 3 Relationship between mean pasture Cu concentration (Days 30 through 141; $x$ ) and maximum liver Cu concentration (Day 99; y), $y=5.3 \pm 1.17 x-15 \pm 32\left(R^{2}=.72, n=10, P<0.001\right)$. Horizontal line at $200 \mathrm{mg} \mathrm{Cu} / \mathrm{kg}$ fresh tissue indicates maximum permissible limit of $\mathrm{Cu}$ in organs for human consumption (NZ Food Regulations 1984).

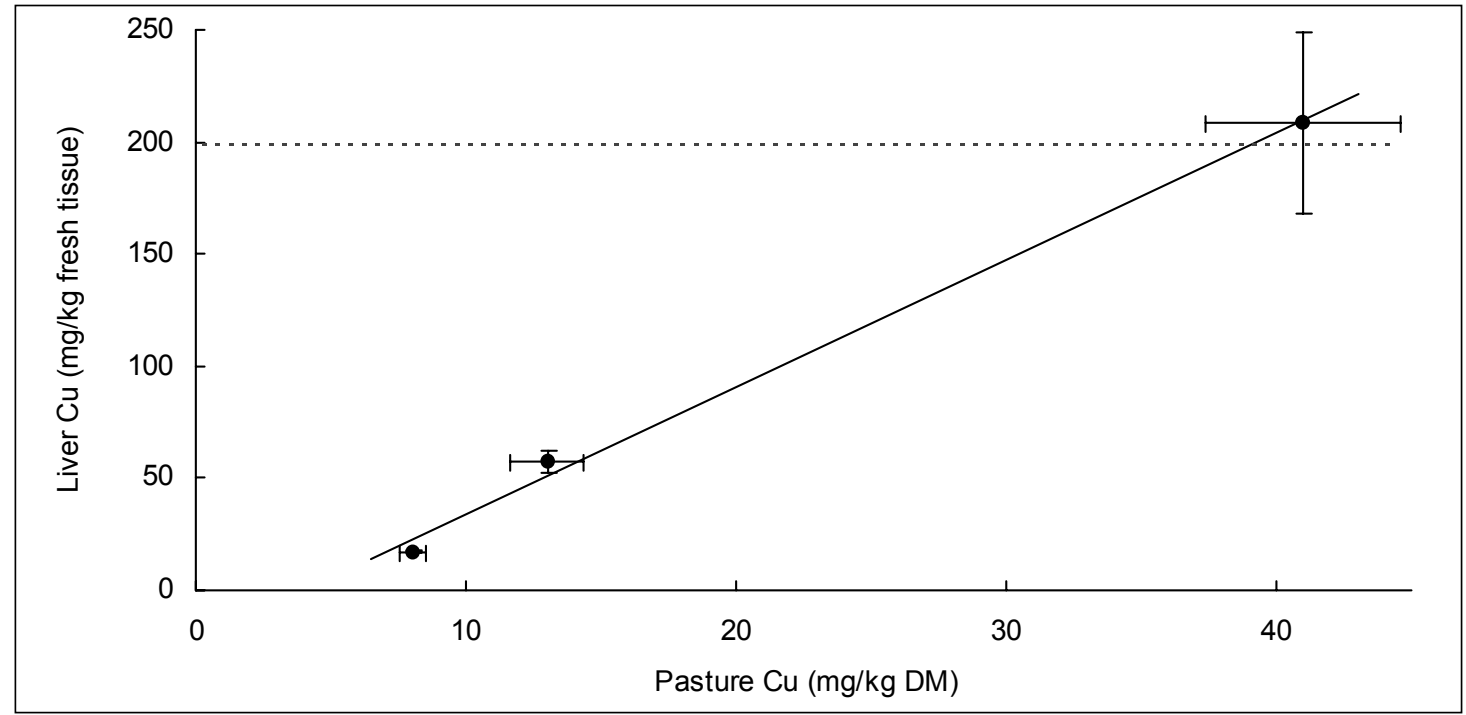

sheep during the trial was $0.79 \pm 0.036 \mathrm{mg} \mathrm{Cu} / 1(12.3$ $\pm 0.63 \mu \mathrm{mol} / \mathrm{l})$. Likewise, $\mathrm{Cu}$ treatments did not affect animal growth. The mean initial and final liveweights of all animals were $31 \mathrm{~kg}$ and $47.4 \pm 0.67 \mathrm{~kg}$, respectively, and the average daily weight gain was 93 $\pm 3.8 \mathrm{~g}$ /day.

Pasture $\mathrm{Cu}(\mathrm{x})$ was a good predictor of liver $\mathrm{Cu}$ concentration (y) in grazing Romney sheep. As shown in Figure 3: $\mathrm{y}=5.3 \pm 1.17 \mathrm{x}-15 \pm 32\left(\mathrm{R}^{2}=0.72, \mathrm{n}=10\right.$, $\mathrm{P}<0.001)$.

\section{Discussion}

Copper application raised $\mathrm{Cu}$ content of herbage on treated pastures and markedly improved the $\mathrm{Cu}$ status of grazing sheep, as assessed by liver $\mathrm{Cu}$ concentrations. 
Based on pasture $\mathrm{Cu}$ concentrations (Figure 1) and estimated mean daily dry matter intakes of $1.6 \mathrm{~kg} /$ day for $39 \mathrm{~kg}$ lambs gaining $100 \mathrm{~g} /$ day (Sykes \& Nicol 1983), mean $\mathrm{Cu}$ intakes were calculated to be 13,21 and $65 \mathrm{mg} \mathrm{Cu} /$ day for animals on the control, lowtreated and high-treated pastures, respectively. These $\mathrm{Cu}$ intakes were reflected in liver $\mathrm{Cu}$ concentrations. Sheep with liver $\mathrm{Cu}$ concentration less than $6 \mathrm{mg} \mathrm{Cu} / \mathrm{kg}$ fresh tissue are $\mathrm{Cu}$ deficient (Grace 1994). When $\mathrm{Cu}$ intake and absorption exceed metabolic demands of the tissues, the excess $\mathrm{Cu}$ accumulates in liver. Liver stores are not simply sequestered but are utilised to maintain tissue $\mathrm{Cu}$ levels when dietary $\mathrm{Cu}$ intake or absorption are inadequate. Thus the effectiveness of a supplementation strategy such as $\mathrm{Cu}$ topdressing is extended beyond the period of increased herbage $\mathrm{Cu}$ concentration because of the carry-over effect of liver $\mathrm{Cu}$ stores. For example, the $\mathrm{Cu}$ concentration of pastures treated with $0.4 \mathrm{mg} \mathrm{Cu} / \mathrm{ha}$ was greater than that of control pastures only through 99 days (Figure 1), but liver $\mathrm{Cu}$ concentration of the grazing sheep was increased and maintained above that of controls for at least 176 days (Figure 2). The rate of mobilisation of $\mathrm{Cu}$ from the liver depends on $\mathrm{Cu}$ dietary intake, absorption, tissue demands, age, breed and any additional metabolic requirements, for example, when animals are pregnant or lactating. Also, interaction of $\mathrm{Cu}$ with other elements, particularly Mo and sulphur, can interfere with adequate $\mathrm{Cu}$ absorption and utilisation (Lee \& Grace 1997). At Ballantrae the pasture Mo concentration was low, averaging $1.1 \pm$ $0.07 \mathrm{mg} / \mathrm{kg}$ DM for all the experimental paddocks.

In contrast, too much $\mathrm{Cu}$ is toxic. If accumulation in the liver exceeds $450 \mathrm{mg}(7000 \mu \mathrm{mol}) \mathrm{Cu} / \mathrm{kg}$ fresh tissue, stress factors can trigger a massive release of $\mathrm{Cu}$ into the bloodstream, resulting in increased blood $\mathrm{Cu}$ concentration, rapid haemolysis, increased blood glutathione and serum enzymes such as aspartate aminotransferase (AST/SGOT), and increased kidney $\mathrm{Cu}$ concentrations (Todd 1969).

Dietary $\mathrm{Cu}$ requirements of lambs range from 3 to 4 $\mathrm{mg} \mathrm{Cu} / \mathrm{kg}$ DM (Grace 1994), and diets are generally recommended to contain less than $20 \mathrm{mg} \mathrm{Cu} / \mathrm{kg} \mathrm{DM}$, otherwise chronic $\mathrm{Cu}$ toxicity can occur. In this study, Romney lambs grazed pastures of mean $\mathrm{Cu}$ concentration $41 \mathrm{mg} \mathrm{Cu} / \mathrm{kg} \mathrm{DM}$ for 176 days without any clinical signs of $\mathrm{Cu}$ toxicity being observed, and their average weight gain was $93 \mathrm{~g} / \mathrm{day}$, which is considered satisfactory for North Island hill country. Excessive $\mathrm{Cu}$ application should be avoided, however, because the maximum permissible limit (MPP) for liver $\mathrm{Cu}$ is 200 $\mathrm{mg}(3130 \mu \mathrm{mol}) \mathrm{Cu} / \mathrm{kg}$ fresh tissue (NZ Food Regulations 1984), and liver and kidneys exceeding the MPP must be rejected for human consumption.
Elemental analysis is usually necessary to accurately monitor and adjust $\mathrm{Cu}$ application, as herbage $\mathrm{Cu}$ concentration resulting from $\mathrm{Cu}$ topdressing will be affected by season, pasture composition and soil type. Greater quantities of $\mathrm{Cu}$ may not lead to longer-lasting effects. Application of $\mathrm{Cu}$ at typical recommended rates of 1 to $2 \mathrm{~kg} \mathrm{Cu} / \mathrm{ha}$ per annum, which should result in pasture $\mathrm{Cu}$ concentrations of $10-20 \mathrm{mg} / \mathrm{kg} \mathrm{DM}$, would have acceptable margins of efficacy and safety (Figure 3), provided that the applied $\mathrm{Cu}$ is washed from herbage into the soil (cf. West et al. 1997).

In this experiment Romney lambs served as the model animal, but significant differences in $\mathrm{Cu}$ metabolism for other sheep breeds have been reported. In the UK, for instance, Welsh Mountain sheep, when compared with Scottish Blackface, were found to have higher plasma $\mathrm{Cu}(0.91$ v. $0.61 \mathrm{mg} \mathrm{Cu} / \mathrm{l})$ and higher liver $\mathrm{Cu}$ concentrations (200 vs $100 \mathrm{mg} \mathrm{Cu} / \mathrm{kg} \mathrm{DM}$ ) because the Welsh Mountain are more efficient at absorbing $\mathrm{Cu}$ (Woolliams et al. 1983; Woolliams et al. 1985). Also, Texel sheep have been shown to be quite sensitive to $\mathrm{Cu}$ poisoning (Woolliams et al. 1982). In New Zealand, where the Texel is becoming popular as a terminal sire, grazing Texel lambs on recently $\mathrm{Cu}-$ treated pasture should be done with caution.

This study supports a recommendation that topdressing pastures with 1 to $2 \mathrm{~kg} \mathrm{Cu} / \mathrm{ha}$ (4 to $8 \mathrm{~kg}$ of $\mathrm{CuSO}_{4} .5 \mathrm{H}_{2} \mathrm{O}$ ) as a safe and effective means of increasing the $\mathrm{Cu}$ intake of grazing animals.

\section{ACKNOWLEDGEMENTS}

Supported by the New Zealand Public Good Science Fund (Contract No. C10622) and Meat New Zealand (Contract No. 96PR-31/1.5).

\section{REFERENCES}

Adams, A.F.R.; Elphic, B.L. 1956. The copper content of some soils and pasture species in Canterbury. New Zealand journal of science and technology 38A: 821-836.

Cunningham, I.J.; Perrin, D.D. 1947. Copper compounds as fertilisers for pastures deficient in copper. Department of Agriculture publication 36. Wellington, New Zealand Department of Agriculture.

Dick, A.T. 1944. Aspiration biopsy of the liver in sheep. Australian veterinary journal 20: 298-303.

Grace, N.D. 1994. Managing trace element deficiencies. AgResearch, Palmerston North.

Grace, N.D.; Knowles, S.O.; Rounce, J.R.; West, D.; Lee, J. 1998. Effect of increasing pasture copper 
concentrations on the copper status of grazing Romney sheep. New Zealand journal of agricultural research 41: 377-386.

Lee, J. 1983. Multi-element analysis of animal tissue by inductively coupled plasma emission spectrometry. ICP information newsletter 8: 553-561.

Lee, J.; Grace, N.D. 1997. A New Zealand perspective on copper, molybdenum and sulphur interactions in ruminants. pp. 25-38. In: Proceedings from the $27^{\text {th }}$ Seminar of the Society of Sheep and Beef Cattle Veterinarians. New Zealand Veterinary Association. Veterinary continuing education publication No. 175. Palmerston North, Massey University.

Mitchell, R.L.; Ruth, J.W.S.; Johnson, I.M. 1957. Trace element uptake in relation to soil content. Journal of the science of food and agriculture 8: 51-59.

New Zealand Food Regulations 1984. Regulation \#257. Wellington, Ministry of Health.

SAS Institute 1987. SAS User's Guide: Statistics. Cary, North Carolina, USA, SAS Institute, Inc.

Sherrell, C.G.; Rawnsley, J.S. 1982. Effect of copper application on copper concentration in white clover and perennial ryegrass on some northland soils and a yellow-brown pumice soil. New Zealand journal of agricultural research 25: 363-368.

Sykes, A.R.; Nicol, A.M. 1983. The energy requirements of the weaned lamb. pp. 121-134. In: Lamb Growth.
Familton, A.R. (ed.) Animal Industries Workshop, Lincoln College.

Todd, J.R. 1969. Chronic copper toxicity of ruminants. Proceedings of the Nutrition Society 28: 189-198.

West, D.M.; Vermunt, J.J; Sargison, N.D. 1997. Copper supplementation of beef bulls - Benefits can be measured. pp. 39-46. In: Proceedings from the $27^{\text {th }}$ Seminar of the Society of Sheep and Beef Cattle Veterinarians. New Zealand Veterinary Association. Veterinary continuing education publication No. 175. Palmerston North, Massey University.

Woolliams, J.A.; Suttle, N.F.; Wiener, G.; Field, A.C.; Woolliams, C. 1982. The effect of breed of sire on the accumulation of copper in lambs, with particular reference to copper toxicity. Animal production 35: 299-307.

Woolliams, J.A.; Suttle, N.F.; Wiener, G.; Field, A.C.; Woolliams, C. 1983. The long-term accumulation and depletion of copper in the liver of different breeds of sheep fed diets of differing copper content. Journal of agricultural science, Cambridge 100: 441-449.

Woolliams, J.A.; Wiener, G.; Woolliams, C.; Suttle, W.F. 1985. Retention of copper in the liver of sheep genetically selected for high and low concentrations of copper in plasma. Animal production 41: 219226. 
